\title{
Bioremediation for Environmental Management
}

\author{
Mahesh Arvind, P. C. Shreedharan, and S. R. Ambika
}

\begin{abstract}
Environmental Management involves control of emissions and effluents into air, water or soil. Bioremediation makes a better effective approach possible. Microbes bioremediate the environment as they biodegrade the pollutants to obtain energy. Among aromatics, phenols and their derivatives form the principal group of environmental contaminants. Even at low levels they are toxic and they pose a threat to the biosphere because of their recalcitrant nature. We have isolated a microorganism which is capable of degrading phenolic compounds even at high concentrations. The available taxonomic evidences have suggested that the bacterial strain is a novel species within the genus Arthrobacter. The microorganism has the ability to degrade various aromatic pollutants. It has been hypothesized that biodegradation of aromatics in soil can be enhanced by introducing plants which exude phenolic compounds through their roots. There is evidence for root exudates enhancing the expression and activity of specific enzymes that degrade aromatics. Plants release $10-20 \%$ of total carbon during photosynthesis through their roots in the soil. Such root exudates are rich in biodegradable organic molecules that stimulate microbial growth. Plants provide nutrients necessary for the microbes to thrive, while microbes provide a healthier soil environment. Aromatic compounds in root exudates such as phenol have been shown to induce dioxygenase enzymes which initiate the biodegradation process. We have made an attempt to show that the enzymes involved in the metabolism of phenolic compounds in the soil bacteria isolated from the contaminated site are induced by the root exudates and the specific activities of the enzymes in the isolate is remarkably high compared to other microorganisms. Hence, bioremediation plays an increasingly important role as a result of new and emerging techniques and processes.
\end{abstract}

Index Terms-Arthrobacter, biodegradation, phenolics, rhizodegradation.

\section{INTRODUCTION}

The environment creates favorable conditions for the existence and growth of all living organisms. The industrial and scientific revolution in the recent past has a tremendous effect on the environment. The various activities involved in this are mainly responsible for polluting the atmosphere.

The level of many pollutants has risen beyond the permissible limits and the environment is slowly becoming lethal to all organisms. A wide variety of synthetic

Manscript received May 12, 2014; revised October 9, 2014.

Mahesh Arvind is with Vijaya College, Bangalore University, Karnataka, India (e-mail: drmhsharv@gmail.com).

P. C. Shreedharan is with the Department of Biological Sciences, School of Natural Science, Bangalore University, Karnataka, India.

S. R. Ambika is with the Department of Botany, Bangalore University, Karnataka, India. chemicals have found their way into the ecosystem as a consequence of industrial activities. The phenolics comprise characteristic pollutants in waste waters and effluents discharged from petrochemical, textile, tannery and coal gasification units.

Bioremediation exploits the catabolic diversity of microorganisms to transform contaminants into less harmful compounds. In this process one can either use the microorganisms already present at the site of contamination or inoculate microorganisms having special catabolic properties. Mixtures of hazardous chemicals can be bioremediated using a mixture of several different strains. This is an alternative approach to the traditional mixed culture technique that employs undefined mixtures of environmental bacteria. The major trends in bioremediation studies include the isolation of microorganisms that exhibit the required biodegradative capacities with regard to specific organic compound and elucidating the catabolic pathways involved. Single strain of bacteria is often chosen, so that biochemical interpretation of the degradation process is simplified.

Phytoremediation is the use of vegetation for treatment of contaminated soils and water. It is applicable at sites containing organic, nutrient or metal pollutants that can be assessed by the roots of plants and degraded or metabolized. Plants can take up and transform organic chemicals to less toxic metabolites. They can stimulate the degradation of organic chemicals in the rhizosphere by the release of root exudates, enzymes and the buildup of organic carbon in the soil (Burken and Schnoor, 1996; Davis et al., 1993) [1], [2]. The root exudates may improve both the bioavailability of hydrophobic organic compounds like PCBs and PAHs, as well as the biodegradation of these chemicals through release of structural analogues for induction of enzymes in the microbial rhizosphere. Aromatic compounds in root exudates have been shown to induce dioxygenase enzymes that degrade polychlorinated biphenyls (Donnelly, et al., 1994; Fletcher and Hedge, 1995; Gilbert and Crowley, 1997) [3]-[5].

Arthrobacter are the basic soil bacteria which have been found to perform several important functions when the earth is poisoned by various harmful chemicals.

An aerobic microorganism with an ability to utilize phenol as carbon and energy source was isolated from contaminated site by employing selective enrichment culture technique. The isolate was identified as Arthrobactercitreus sp. based on morphological, physiological and biochemical tests. The microorganism had additional ability to degrade benzene, benzoic acid, naphthol and cresols (Chandrakanth Karigar et al., 2006) [6].

The present study reports that the root exudates enhance the expression and activity of specific enzymes that degrade phenolics in the isolate. 


\section{MATERIALS AND MethodS}

\section{A. Organism Source, Culture Conditions, and Identification}

The bacterium was isolated from the soil collected from the contaminated sites of Vrishabhavathi stream. The organism was maintained and propagated on nutrient-agar and substrate-mineral salt media. For purification of the bacterial strain, the microorganism was grown on nutrient agar medium. For metabolic studies the bacterial strains were grown on mineral-salt medium (MSM) containing (g/lt: $\mathrm{K}_{2} \mathrm{HPO}_{4}, 1.6 ; \mathrm{KH}_{2} \mathrm{PO}_{4}, 0.2 ;(\mathrm{NH} 4)_{2} \mathrm{SO}_{4}, 1.0 ; \mathrm{MgSO}_{4}$. $7 \mathrm{H}_{2} \mathrm{O}, 0.2 ; \mathrm{NaCl}, 0.1 ; \mathrm{CaCl}_{2} \cdot 2 . \mathrm{H}_{2} \mathrm{O}, 0.02 ; \mathrm{FeSO}_{4} . \mathrm{H}_{2} \mathrm{O}, 0.01$; $\mathrm{Na}_{2} \mathrm{MoO}_{4} .2 \mathrm{H}_{2} \mathrm{O}, 0.5 ; \mathrm{MnSO}_{4} \cdot \mathrm{H}_{2} \mathrm{O}, 0.5 ; \mathrm{Na}_{2} \mathrm{WO}_{4} .2 \mathrm{H}_{2} \mathrm{O}, 0.5$. The growth substrate $(5 \mathrm{mM}$ phenol) was supplemented to the sterilised mineral salt medium aseptically. The flasks were then inoculated with $5 \%$ of inoculum aseptically and were incubated at $25^{\circ} \mathrm{C}\left( \pm 2^{\circ} \mathrm{C}\right)$ on a rotary shaker for 24 hours. Uninoculated flasks were incubated in parallel as controls.

\section{B. Growth Study of the Organism}

The bacterial cells isolated by substrate enrichment culture were used for the growth study. Various phenolic compounds served as source of carbon and energy. The cells were freed from adhering substrate by centrifugation $(5000$ $\mathrm{rpm})$ at $5^{\circ}$ for $20 \mathrm{~min}$. The cells were repeatedly washed with $0.05 \mathrm{M}$ phosphate buffer $(\mathrm{pH} 7.0)$ and centrifuged. The cell pellet obtained was finally re-suspended in the sterile mineral-salt medium. Suitable aliquots $(2.0 \mathrm{ml})$ of this cell suspension were inoculated to the flasks containing different phenolic compounds (5 mM each of 4-nitrophenol, 4chlorophenol and 4-methyl phenol). The growth of the organism was measured turbidometrically by monitoring the OD at $600 \mathrm{~nm}$ at different incubation periods. 4-nitrophenol, 4- chlorophenol and 4-methyl phenol utilization was followed by estimating residual substrate colorimetrically at $600 \mathrm{~nm}$.

\section{Degradation of Phenolic Compounds}

The ability of the organism to degrade phenol, 4nitrophenol, 4-chlorophenol and 4-methyl phenol was determined by solvent extraction of the residual 4nitrophenol from the spent medium at specific time intervals. Growth was measured by determining OD at 600 nm with SL 159, ELICO Spectrophotometer.

The extract was dried and the metabolites were purified by TLC and characterized by UV-Spectroscopy.

\section{Enzyme Assays}

Enzyme activities relating to the catabolism of phenol such as hydroxylase (Monooxygenase) and catechol-2, 3dioxygenase activity was measured spectrophotometrically in quartz cuvettes at $25^{\circ} \mathrm{C}$. Reaction mixtures contained in a total volume of $3.0 \mathrm{ml}$, contained $1.8 \mathrm{ml}$ (18m moles) sodium phosphate buffer ( $\mathrm{pH} 7.0), 0.1 \mathrm{ml}$ enzyme (protein content $\left.2.0 \mathrm{mg} \mathrm{ml}^{-1}\right)$ and $1.0 \mathrm{ml}$ of substrate $(0.75 \mathrm{~m}$ moles of phenol). Phenol hydroxylase/monooxygenase activity was measured by following the formation of catechol at 270 nm. Catechol-1, 2 - dioxygenase activity was determined by monitering the formation of cis-muconic acid at $260 \mathrm{~nm}$. Catechol-2, 3-dioxygenase activity was monitored at 276 nm.

$50 \mathrm{ml}$ of MSM along with $25 \mathrm{mg}$ phenol and the isolate was autoclaved and incubated for 25 hours with constant shaking. The mixture was centrifuged and the residue (cell extract) was inoculated to $50 \mathrm{ml}$ of phosphate buffer $(\mathrm{pH}$ : 7.0) containing $25 \mathrm{mg}$ phenol. This mixture was autoclaved and incubated for three hours. $5.0 \mathrm{ml}$ of aliquots was withdrawn at every one hour and saturated with $2.8 \mathrm{~g}$ of ammonium sulphate using a magnetic stirrer in an ice bath and stored overnight. The mixture was centrifuged and the residue was used for electrophoresis.

Similarly, glucose was taken instead of phenol along with the isolate for the enzyme assay. The residue obtained was also subjected to electrophoresis.

The sample was mixed with glycerol and the tracking dye, bromophenol blue. $150 \mathrm{ml}$ of this sample was carefully layered on to the surface of the spacergel. The tubes were electrophoresed at $2 \mathrm{~mA}$ current per gel tube until the tracking dye reached the bottom of the gel tubes. After completion of the run the tubes were removed from the apparatus and water was injected between the gel and internal surface of the glass tubes by a syringe needle without injuring the gel. The gel tubes were gently rotated so that the gels slideout. The gels were then stained for enzyme activity and protein.

\section{RESUltS AND DiscUSSION}

\section{A. Description of the Organism}

Based on phenotypic characteristics such as cell wall type, morphology, motility and nutritional requirements the bacteria capable of degrading phenolics is classified as Arthrobacter citreus strain. The strain growing on phenolics is Gram positive, exhibited typical rodcoccus transition, aerobic, motile and assimilated glucose, galactose, lysine, threonine, and alanine and did not require vitamin. The organism is a mesophile and has optimal growth at $\mathrm{pH} 7.0$ and at $25^{\circ} \mathrm{C}$ (see Table I).

TABLE I: RESUlTS OF VARIOUS MORPHOLOGICAL TESTS

\begin{tabular}{|l|l|l|}
\hline No. & \multicolumn{1}{|c|}{ TESTS } & \multicolumn{1}{|c|}{ OBSERVATIONS } \\
\hline 1 & Form & Rods \\
\hline 2 & Cell grouping & Short Chains \\
\hline 3 & Size & $1.6 \mathrm{~mm} \times 3.2 \mathrm{~mm}$ \\
\hline 4 & Gram stain & Positive \\
\hline 5 & Motility & Motile \\
\hline 6 & Flagella & Present \\
\hline 7 & Endospores & Absent \\
\hline 8 & Catalase & Positive \\
\hline 9 & $\begin{array}{l}\text { Oxidative fermentation } \\
\text { Glucose }\end{array}$ & Positive \\
\hline 10 & Vitamin requirement & Negative \\
\hline
\end{tabular}

Studies on the degradation of phenolic compounds by Arthrobacter citreus strain indicated that $5 \mathrm{~mm}$ phenol, 4.2 $\mathrm{mM}$ 4-nitrophenol, 3mM 4-chlorophenol and $1.8 \mathrm{mM} 4-$ methyl phenol utilization occurred in 24 hours. The organism tolerated phenol concentration upto $22 \mathrm{mM}$, 4- 
nitrophenol concentration upto $15 \mathrm{mM}$, 4-chlorophenol concentration upto $12 \mathrm{mM}$ and 4-methyl phenol concentration upto $6 \mathrm{mM}$. TLC analysis and spectrophotometric analysis of the metabolic intermediates suggest that phenol is degraded to catechol, 4-nitrophenol is degraded to 4-nitrocatechol, 4-chlorophenol to 4-chloro catechol and 4-methyl phenol to 4-methyl catechol and then to hydroxyquinol owing to further metabolism. The Rf value and the UV spectrum of the metabolite agreed well with the authentic sample of catechol, 4-nitrocatehol, 4chlorocatechol and 4-methyl catechol as intermediary metabolites in the metabolism of the phenolic compounds. Replacement culture methods also support the role of catechol, 4-nitrocatechol, 4-chlorocatechol and 4-methyl catechol as intermediary metabolites in the metabolism of phenolic compounds.

Results presented here indicate that atleast one monooxygenase enzyme is able to hydroxylate substituted phenols. The product of the initial reaction undergoes an oxygenase catalyzed removal of the substituent group forming hydroxyquinol. Hydroxyquinol undergoes ring fission to maleylacetic acid, which can be readily degraded via $\beta$-Ketoadipic acid. Studies with cell extracts clearly show that a dioxygenase enzyme catalyses the subsequent conversion of hydroxyquinol to maleylacetic acid. The Arthrobacter citreus studied here appears to use the monooxygenase catalyzed reaction since it is clear that the system converts catechol, 4-nitrocatechol, and 4chlorocatechol and 4-methyl catechol to hydroxyquinol.

\section{B. Enzymatic Assays}

The metabolic pathway adopted by the Arthrobacter sp. for the degradation of phenol was confirmed by assaying for the probable key enzymes involved. The activities of phenol monooxygenase and catechol-2,3-dioxygenase were investigated by spectrophotometric methods using the cell free extracts (see Table II). The protein induction pattern was studied by PAGE analysis and the band pattern observed has been shown (see Fig. 1).

Different microorganisms are found to degrade phenol. The efficiency of Arthobacter citreus is found to be relatively high $(22 \mathrm{mM})$ when compared to Arthrobacter psychrophendicus sp. nov.

(10 mm) (Rosa Margesin et al. 2004) [7], Pseudomonas sp. TCP 114 (18-20 mm), Arthrobacter sp. CPR 706 (16-20 $\mathrm{mm})$, Aureobasidium (10 $\mathrm{mm})$, Rhodoturula $(10 \mathrm{~mm})$, TrichosporonLE 3 (18 mm), Comamonas testosterone $\mathrm{P}_{15}$

$(15 \mathrm{~mm})$, Comomonas testosterone E $23(20 \mathrm{~mm})$ and Trichosporoncutaneum $(5.3 \mathrm{~mm}$ ( (vera L. Santos and Valter R. Linardi 2001) [8].

Similarly 4-chlorophenol degradation by Arthrobacter citreus is found to be relatively very high $(12 \mathrm{~mm})$ when compared to Arthrobacter pscychroplenolicussp. nov. (175 ppm) (Rosa Margesin et al. 2004) [7], Pseudomonas sp. TCP 114 (1.5 mm), and Arthrobacter sp. CPR 706 (0.5 $0.55 \mathrm{~mm}$ ) (vera L. Santos and Valter R. Linardi, 2001) [8].

The enzyme activity of phenol hydroxylase and catechol 1, 2 dioxygenase from free cell extracts of various microorganisms was also compared and Arthrobacter citreus is found to be more efficient. The phenol hydroxylase activity of Arthrobacter citreus was found to be
$46 \mathrm{Umg} /$ protein when compared to Trichosporonsp. LE 3 (0.132), LE 4 (0.052), Aurebasidiumsp. FE 6 (0.021), FE 7 (0.026), FE 9 (0.032), FF 13 (0.028) and Rhodotorulasp. F1B 22 (0.099), AF1 (0.009), AF3 (0.007), LE 1 (0.019), LE 2 (0.038), FE 1 (0.009), FE 3 (0.008), FE 11 (0.017) (vera L. Santos and Valter R. Linardi, 2001) [8].

Catechol-1, 2-dioxygenase activity was also found to be very efficient and relatively high in Arthrobacter citreus (02 Umg/protein) when compared to Trichosporonsp. LE 3 (1.395), LE 4 (0.516), Aurebasidiumsp. FE 6 (0.216), FE 7 (0.244), FE 9 (0.032), FF 13 (0.267) and Rhodotorulasp. F1B 22 (0.199), AF1 (0.072), AF3 (0.063), LE 1 (0.100), LE 2 (0.359), FE 1 (0.083), FE 3 (0.093), FE 11 (0.158) (vera L. Santos and Valter R. Linardi 2001) [8].

TABLE II: SPECIFIC ACTIVITIES OF CATABOLIC ENZYMES IN CRUDE EXTRACTS OF ARTHROBACTER SP. (A) CELLS GROWN ON PHENOL (B) CELls Grown ON GLuCOSE

\begin{tabular}{|c|c|c|c|}
\hline \multirow{2}{*}{ No. } & Enzyme & \multicolumn{2}{|c|}{$\begin{array}{c}\text { Specific Activity } \\
\text { U/mg protein }\end{array}$} \\
\cline { 3 - 4 } & & (a) & (b) \\
\hline 1 & Phenol hydroxylase & 46 & 02 \\
\hline 2 & Catechol - 2, 3 - dioxygenase & 54 & 03 \\
\hline 3 & Catechol - 1,2 - dioxygenase & 02 & 01 \\
\hline
\end{tabular}

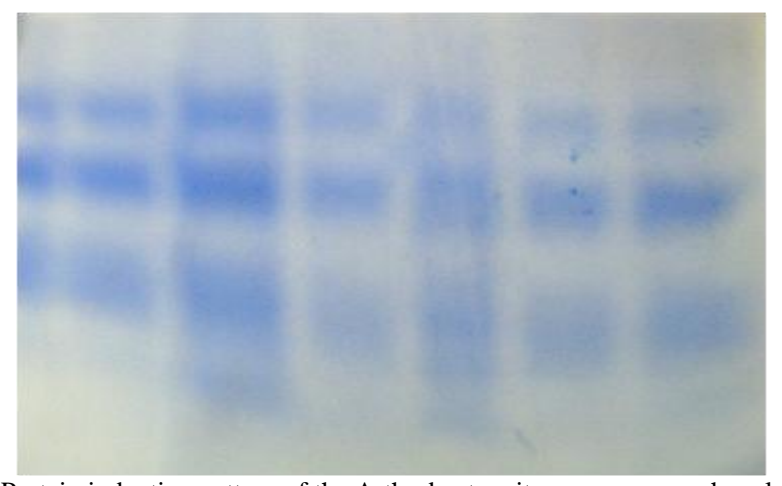

Protein induction pattern of the Arthrobacter citreus grown on phenol.

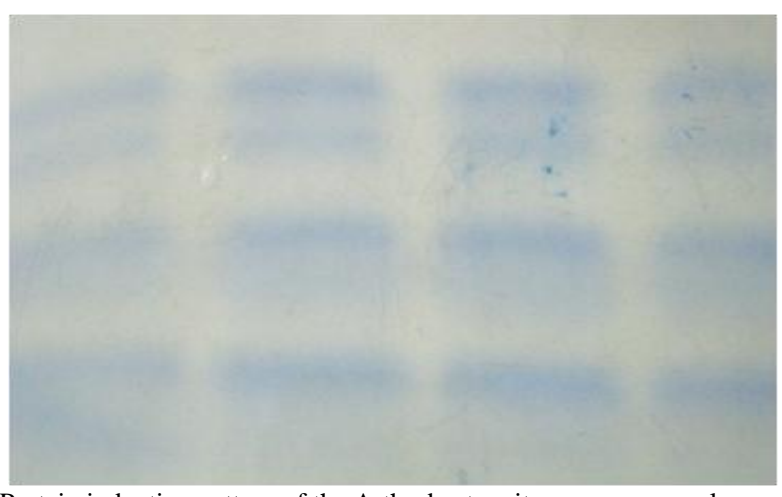

Protein induction pattern of the Arthrobacter citreus grown on glucose Fig. 1. Protein Induction Pattern.

\section{CONCLUSION}

The present study reports that the isolated, Arthrobacter citreus strain which has already been adapted to grow on phenol has an additional ability to degrade 4- nitrophenol, 4chlorophenol and 4-methyl phenol. The organism also has additional capacity to utilize benzene, benzoic acid and naphthol as substrates. 
The metabolism of the phenolic compounds by this strain occurred through the involvement of catechols as key intermediates. The isolation of hydroxyquinol as a metabolic intermediate suggests that the phenolic compounds are hydroxylated by a monoxygenase which are further cleaved in a dioxygenase mediated reaction were they are metabolized by $\beta$-ketoadipate pathway.

The study reveals that Arthrobacter citreus strain can efficiently degrade the phenolic compounds even at higher concentrations. The bacteria can often adapt to degrade the contaminants if given sufficient time. Since the organism is capable of degrading 4-nitrophenol, 4-chlorophenol, 4methylphenol and other toxic aromatics, there is a high potential for its use in the development of microbial technology for bioremediation. Understanding the physiology and genetics of degradation of phenolics will be helpful in designing strategies for bioremediation of contaminated environments.

The presence of phenol in the soil is from the root exudates. This has induced the enzymes which initiate the degradation of phenol compounds and other aromatic compounds in the bacteria. The specific activity in the isolate is relatively high compared to other microorganisms due to the root exudates.

\section{REFERENCES}

[1] J. G. Burken and J. L. Schnoor, "Phytoremediation-plant uptake of atrazine and role of root exudates," J. of Environ. Engineering, vol. 122, pp. 958-963, 1996.

[2] L. C. Davis, J. F. Shimp, J. C. Tracy, E. Lee, W. Huang, L. E. Erickson, and J. L. Schnoor, "Beneficial effect of plants in the remediation of soil and ground water contaminated with organic materials," Crit. Rev. Environ SciTechnol, vol. 23, pp. 41-77, 1993.

[3] P. K. Donnelly, R. S. Hedge, and J. S. Fletcher, "Growth of PCB degrading bacteria on compounds from photosynthetic plants," Chemosphere, vol. 28, pp. 981-988, 1994.

[4] J. S. Fletcher and R. S. Hedge, "Release of phenol by perennial plant roots and their potential importance in bioremediation," Chemosphere, vol. 31, pp. 3009-3016, 1995.

[5] E. S. Gilbert and D. E. Crowley, "Plant compounds that induce polychlorinated diphenyl biodegradation by Arthrobacter sp. strain B1B," Appl. Environ. Microbiol, vol. 63, pp. 1933-1938, 1997.

[6] C. Karigar, A. Mahesh, M. Naganahalli, and D. J. Yun, "Phenol degradation by immobilized cells of Arthrobacter citreus," Biodegradation, vol. 17, pp. 47-55, 2006.

[7] R. Margesin, P. Schumann, C. Sporoer, and A. M. Gounot, "Arthrobacter psychrophenolicus sp. nov., isolated from an alpine ice cave," Int. J of sys \&Evol. Micro., vol. 54, pp. 2067-2072, 2004.

[8] V. L. Santos and V. R. Linardi, "Phenol degradation by yeasts isolated from industrial effluents," J. Gen. Appl. Microbiol., vol. 47, pp. 213-221, 2001.

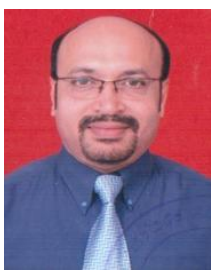

Mahesh Arvind is a professor of biochemistry at Vijaya College affiliated to Bangalore University, Karnataka, India. He obtained his M.Sc and M.Phil degrees from Bangalore University, $\mathrm{Ph} . \mathrm{D}$ degree from Dr. MGR University and Research Institute, Chennai. He has received Honarary Fellowships for outstanding contributions in the field of science from International Society of Ecological Communications, Society of Sciences and Society of Environmental Sciences. His research area is microbial degradation of pollutants and phytoremediation. $\mathrm{He}$ has a number of papers that have been published in reputed journals and presented at prestigious seminars, conferences, trainings and symposia. $\mathrm{He}$ is asociated with research projects on Lake Conversation Plan, Hazardous Biomedical and Solid waste management. He is a research advisor/Guide for the research scholars of Deemed Universities. 